\title{
Chromobacterium violaceum: a fatal case in the northeast of the Brazil
}

\section{Chromobacterium violaceum: um caso fatal no nordeste do Brasil}

Maria José de Britto Costa Fernandes ${ }^{1}$; Kleber Giovanni Luz ; Leonardo de Albuquerque Dantas ${ }^{3}$; Maria Celeste Nunes de Melo ${ }^{4}$; Dulce Almeida ${ }^{4}$

\begin{abstract}
Chromobacterium violaceum is a rare pathogen that can potentially cause fatal infections in humans. An 8-year-old child from Natal, northeast of Brazil, presented history of fever, sore throat, and abdominal pain, during 5 days before admission, and died 4 hours after hospitalization. Chromobacterium violaceum was isolated from oropharynx scrapings and was resistant to ampicillin, cefotaxime, cefalotin, ceftazidime, and ceftriaxone.
\end{abstract}

Key words: Chromobacterium violaceum; opportunistic infection; Brazil.

\section{INTRODUCTION}

Chromobacterium violaceum, a Gram negative bacilli, facultative aerobic, found in the water and soil of tropical and subtropical regions, has been recently recognized as an opportunistic pathogen that may cause liver, lung, and skin abscesses, as well as serious septicemias in human and other animals $^{(6,9)}$. Other reports associating $C$. violaceum to chronic granulomatous disease, osteomyelitis, periorbital cellulitis, and ocular infection have been described in the literature ${ }^{(2,4,6,11)}$. These infections, although rare are characterized by rapid dissemination and high mortality ${ }^{(5,12)}$

\section{CASE REPORT}

An 8-year-old female patient was assisted at Children's Hospital in the city of Natal, northeast of the Brazil. She presented clinical signs of pharyngoamygdalitis that resulted in death 4 hours after hospitalization. At hospital admission she presented history of fever, sore throat, and abdominal pain during the 5 previous days.
Scrapings from the oropharynx were scattered over the surface of the followings: Nutrient Agar, MacConkey Agar, Blood Agar, incubated at $37^{\circ} \mathrm{C}$ under aerobic and microaerophilic conditions. After 24 hours of incubation, a pure culture of violaceus colonies grew on the surface of the mediums and, subsequently, proved to be Gram negative bacillus, motile, catalase-positive, oxidasepositive, glucose fermenter producing acid without gas (Figure). Other positive biochemical tests, such as nitrate reduction and arginine decarboxylation, along with abundant production of purple pigment, confirmed the presence of $C$. violaceum. This microorganism in vitro was sensitive to tetracycline $(30 \mu \mathrm{g})$, chloramphenicol $(30 \mu \mathrm{g})$, gentamicin $(10 \mu \mathrm{g})$, netilmicin $(30 \mu \mathrm{g})$, aztreonam $(30 \mu \mathrm{g})$, sulphazothrim $(25 \mu \mathrm{g})$, pefloxacin $(5 \mu \mathrm{g})$, and ciprofloxacin $(5 \mu \mathrm{g})$; and is resistant to ampicillin $(10 \mu \mathrm{g})$, cefotaxime $(30 \mu \mathrm{g})$, cefalotin $(30 \mu \mathrm{g})$, ceftazidime $(30 \mu \mathrm{g})$, and ceftriaxone $(30 \mu \mathrm{g})$.

Laboratory investigations showed: hemoglobin $8.4 \%$, leukocyte count of 2,900, with $79 \%$ neutrophils, $74 \%$ segmented neutrophils, 19\% lymphocytes, and $0 \%$ eosinophils; platelet count of 142,000, and a more hypoxemic metabolic acidosis as demonstrated by gasometry.

First submission on $06 / 02 / 13$; last submission on 23/06/14; accepted for publication on $01 / 7 / 14$; published on 20/08/14

1. MSc in Genetics and Molecular Biology-Universidade Federal do Rio Grande do Norte (UFRN); professor of Microbiology-UFRN.

2. PhD in Infectious and Parasitic Diseases-Universidade de São Paulo (USP); professor of Infectious Diseases-UFRN.

3. Biomedician-UFRN.

4. PhD in Microbiology-Universidade Federal do Rio de Janeiro (UFRJ); professor of Microbiology-UFRN. 


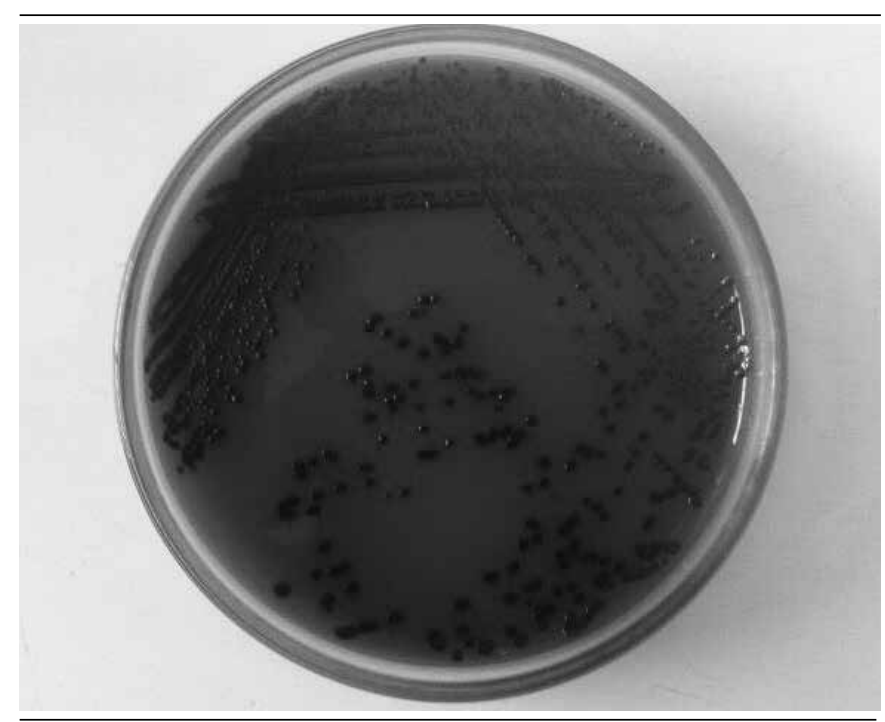

FIGURE - Pigmented colonies observed on the blood agar plate after 24 hours of incubation, typical of Chromobacterium violaceum

\section{DISCUSSION}

Chromobacterium violaceum is an uncommon, but potentially life-threatening infection in humans with very high fatality rate ${ }^{(1,7,10)}$. A number of chromobacteriosis cases have been sporadically reported in Brazil ${ }^{(3,8,9)}$ and although the infections is rare, C. violaceum seems to be an etiologic agent of serious community infections, as well as conducive to hospital infections ${ }^{(9)}$. Due to the bacteriological data obtained from the material scraped from patient's oropharynx, the rapid evolution of the case and the tropical climate of the coast region of the State of Rio Grande do Norte, Brazil, we suggest that the microorganism responsible is C. violaceum. This fact, added to other cases described ${ }^{(3,8,9)}$, reinforces the need for introducing methods into the laboratory routine aiming to diagnosing chromobacteriosis.

\section{RESUMO}

Chromobacterium violaceum é um patógeno raro que potencialmente pode causar infecções fatais em bumanos. Relatamos o caso de uma criança de 8 anos de idade, moradora da cidade de Natal, nordeste do Brasil, que apresentou história de febre, dor na garganta e no abdome durante os cinco dias anteriores à internação, e veio a falecer após 4 boras de hospitalização. A bactéria Chromobacterium violaceum foi isolada da orofaringe e apresentou resistência a ampicilina, cefotaxima, cefalotina, ceftazidima e ceftriaxona.

Unitermos: Chromobacterium violaceum; infecção oportunista; Brasil.

\section{REFERENCES}

1. CHATTOPADHYAY, A. et al. Chromobacterium violaceum infection: a rare but frequently fatal disease.J Pediatr Surg, v. 37, n. 1, p. 108-10, 2002.

2. CHEN, C. H. et al. Chromobacterium violaceum bacteremia: a case report.J Microbiol Immunol Infect, v. 36, n.1, p. 141-4, 2003.

3. de SIQUEIRA, I. C. et al. Chromobacterium violaceum in siblings, Brazil.Emerg Infect Dis, v. 11, n. 9, p. 1443-5, 2005.

4. FELDMAN, R. B. et al. Chromobacterium violaceum infection of the eye: a report of two cases. Arch Ophthalmol, v. 102, n. 5, p.711-3, 1984.

5. GUEVARA, A. et al. Sepsis por Chromobacterium violaceum pigmentado y no pigmentado. Rev Chil Infect, v. 24, n. 5, p. 402-6, 2007.

6. MACHER, A. M. et al. Chronic granulomatous disease of childhood and Chromobacterium violaceum infections in the southeastern United States. Ann Intern Med, v. 97, n. 1, p. 51-4, 1982.
7. MARTINEZ, P. et al. Fatal septicemia caused by Chromobacterium violaceum in a child from Colombia. Rev Inst Med Trop Sao Paulo, v. 49, n. 26, p. 391-3, 2007.

8. MARTINEZ, R. et al.Chromobacterium violaceum infection in Brazil: a case report. Rev Inst Med Trop Sao Paulo, v. 42, n. 2, p. 111-3, 2000.

9. SANTOS, 0. H. L. R. et al. Infecção comunitária e hospitalar por Chromobacterium violaceum. Braz J Infect Dis, v. 3, n. 1 p. 105, 1999.

10. SHAO, P. L. et al. Chromobacterium violaceum infection in children: a case of fatal septicemia with nasopharyngeal abscess and literature review. Pediatr Infect Dis J, v. 21, n. 7, p. 707-9, 2002.

11. SIRINAVIN, S. et al. Invasive Chromobacterium violaceum infection in children: case report and review. Pediatr Infect Dis J, v. 24, n. 6, p. 559$61,2005$.

12. TEOH, A. Y. B. et al. Fatal septicemia from Chromobacterium violaceum: case reports and review of the literature. Hong Kong Med J, v. 12, n. 3, p. 228-31, 2006.

\section{MAILING ADDRESS}

Maria José de Britto Costa Fernandes

Rua desembargador Sinval Moreira Dias, 1.709; Lagoa Nova; CEP: 59056-310; Natal-RN, Brazil; e-mail: majofernandes@gmail.com. 